\title{
ANALISIS PENGARUH LEBAR CELAH UDARA PADA CHANNEL OUTLET TERHADAP KONDISI RUANGAN DAN DAYA LISTRIK DENGAN MEMANFAATKAN PANEL SURYA
}

\author{
Antan Noraidi Maulana'), Achmad Kusairi Samlawi'), Muhammad Rijali ${ }^{3)}$ \\ 1), 2)Program Studi Teknik Mesin Fakultas Teknik Universitas Lambung Mangkurat \\ JL. Akhmad Yani Km.36 Banjarbaru, Kalimantan Selatan,70714 \\ ${ }^{3}$ Program Studi Teknik Mesin, Akademi Teknik Pembangunan Nasional, \\ JL. Ir. P.M, Noor No: 10 Simpang Empat Banjarbaru, Kalimantan Selatan, \\ E-mail : anaebo3@gmail.com,
}

\begin{abstract}
Only a Part of the energy of sunlight is absorbed by solar panels during the day will be converted into electrical energy, the rest will be converted into thermal energy that conducted to the solar panel surface with high surface temperatures. High temperatures on the surface of solar panels can be combined as a trombe wall to produce a temperature gradient in the channel outlets or vents. The produced gradient temperature will create air flow velocity in the chamber and will increase due to the difference in density gradient. So heat in the room will be pushed out. This study will vary, the air gap width $3 \mathrm{~cm}, 4.5 \mathrm{~cm}$ and $6 \mathrm{~cm}$ by comparing the indoor temperature, humidity and electric power by using solar panels and without 450 tilted solar panel facing north. Room dimensions are 0.5x0.5x0.5 m, with solar panels 150x180x18 $\mathrm{mm}$ dimensions. Collecting data every 10 minutes from 07:00 until 19:00. The sensor used is LM35, DHT11, Voltage Sensor, and ACS712. Air condition obtained will be compared with the standard of comfort of air in the tropical building. Results obtained from the research is a widening gap Outlet Channel or ventilation in the room conditions will increase the temperature, the humidity, increase power and decrease the comfort in the room. Otherwise the narrow width of the gap or ventilation Outlet Channel it will lower the temperature, increase humidity, lower power and increased comfort in the room.
\end{abstract}

Keywords : Channel Outlet, Air Temperature, Electrical Power

\section{PENDAHULUAN}

Pemanasan global ini membuat para peneliti di Indonesia mencari alternatif lain untuk menciptakan suatu kondisi ruangan maupun bangunan yang nyaman bagi manusia. Yakni dengan cara menghangatkan atau mendinginkan ruangan. Pada proses sistem yang ada memerlukan kerja dari listrik untuk mengubah temperatur ruangan. Namun demikian tetap saja membutuhkan energi yang tidak renewable.

Untuk mencapai kondisi ruangan normal yang nyaman pada daerah tropis dalam hal ini sebagai pengkondisian udara untuk pendingin ruangan, maka diperlukan kecepatan aliran udara yang cukup untuk kondisi tersebut. Ada banyak faktor yang mempengaruhi kecepatan aliran udara pada ruangan. Salah satu hal yang mempengaruhi kecepatan aliran adalah celah outlet pada channel atau ventilasi.

Oleh sebab itu pada penelitian ini bertujuan untuk mengetahui dampak dari variasi lebar celah terhadap kenyamanan ruangan untuk daerah tropis dan mengetahui daya listrik yang dihasilkan. 


\section{TINJAUAN PUSTAKA}

Febrita, Y. (2011) telah melakukan penelitian ventilasi solar chimney dengan membandingkan hasil penelitian yang dilakukan oleh Jyotirmay (2006), Nugroho (2006) dan Chitsomboon (2004), dimana pokok bahasan yang sama yaitu mengenai solar chimney ventilation. Perbandingan bertujuan untuk menentukan sampai sejauh mana parameter desain solar chimney ventilation dapat

meningkatkan kecepatan udara di dalam bangunan pada daerah tropis lembab. Dari hasil penelitian ini menunjukan bahwa penelitian Jyotirmay (2006) memiliki desain kecepatan angin yang paling tinggi yaitu meningkatkan arus ventilasi $36.85 \%$ pada radiasi matahari 949.53 $\mathrm{W} / \mathrm{M}^{2}$ dengan dimiringkan $45^{\circ}$.

Koyunbaba, dkk (2012) telah melakukan penelitian tentang perbandingan performa sistem Trombe Wall penghangat ruangan dengan menggunakan variasi kaca, kaca ganda, dan semi transparan yaitu PV pada bagian exteriornya.

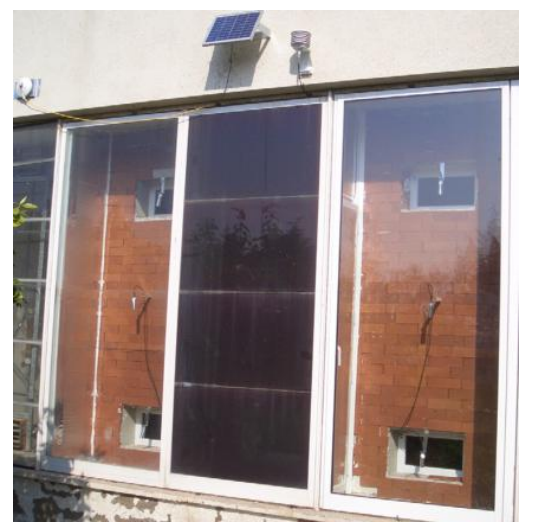

Gambar 1. Aplikasi pemasangan PV-Trombe Wall

Hasil penelitian dengan menggunakan PV panel sebagai Exteriornya didapatkan maximum temperatur $24^{\circ} \mathrm{C}$ pada jam 14.00 dan radiasi yang diserap sebanyak $793,78 \mathrm{~W} / \mathrm{m}^{2}$ pada jam 13.00 tanggal 26 februari. Efisiensi elektrik pada semi transparan solar sell di dapatkan sekitar $4.5 \%$.

Wei, Sun. (2010) telah melakukan penelitian tentang performa dinding trombe yang dikombinasikan dengan PV panel sebagai pelapis kaca pada exteriornya dan menambahkan jendela disampingnya dengan menghadapkan ke arah selatan. Penambahan jendela diharapkan dapat menambah pemanasan ruangan. Penelitian ini dilaksanakan pada musim dingin dengan letak garis lintang $37,86^{\circ}$ di negara China. Kemudian dimensi dari dinding trombe yang dikombinasikan dengan PV Panel memiliki lebar 0,83 m, tinggi $2.6 \mathrm{~m}$, dan lebar celah antara 
panel surya dengan dinding trombe adalah $0.18 \mathrm{~m}$. Pada jendela dipasang double kaca dengan ukuran $1.2 \mathrm{~m}$ x $1.2 \mathrm{~m}$.

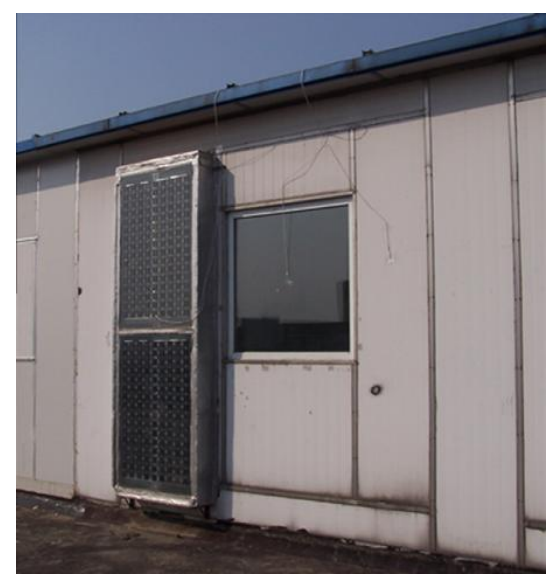

Gambar 2. Aplikasi PVTW dengan jendela pada bangunan

Penelitian ini menggunakan dua metode berbeda yaitu dengan simulasi dan data experimental. Hasil dari penelitian ini menunjukan bahwa desain dinding trombe yang dikombinasikan dengan panel surya ditambahkan jendela pada sisi sampingnya dengan menghadapkan ke arah selatan pada musim dingin adalah terjadi pengurangan efisiensi thermal pada PVTW (PV-Trombe Wall) sebesar 27\%, kemudian dampak penambahan PV panel pada lapisan kaca dapat menurunkan efisiensi thermal sebesar $17 \%$. Total efisiensi pemanfaatan energi surya berkurang sebesar 5\% dan Efisiensi elektrik yang didapat sebesar 11.6\%.

Dinding trombe merupakan sistem pemanas pasif yang diciptakan dan dipatenkan pada tahun 1881 oleh Edward Morse. Nama Trombe diambil dari salah satu insinyur Perancis dan arsitek yang dipopulerkan pada tahun 1964 yakni Felix Trombe dan Jacques Michel. Dinding ini dilapisi dengan kaca pada sisi external yang dipisahkan oleh celah udara. Lalu cahaya matahari yang tembus melewati kaca dalam spektrum elktromagnetik berupa sinar ultra violet akan diserap oleh dinding dan dipancarkan lagi dalam spektrum inframerah ke celah udara oleh dinding tersebut. Dinding trombe menyimpan panas dari matahari dan melepaskan panas ke dalam ruangan atau bangunan di malam hari. Pada daerah tropis dinding trombe dihadapkan ke arah utara untuk memaksimalkan paparan surya yang diterima dan bahan yang digunakan pada dinding ini terbuat dari bahan yang memiliki kapasitas panas tinggi atau bahan yang bersifat menyimpan panas seperti beton dan air.

Di daerah tropis dinding trombe digunakan sebagai pengkondisian udara untuk mendinginkan ruangan. Panas yang tersimpan dikondisikan supaya tidak masuk ke dalam ruangan namun panas tersebut dikondisikan agar memanaskan celah udara yang berada diantara dinding dan kaca. Perbedaan temperatur yang dihasilkan antara celah udara dengan ruangan 
menyebabkan perbedaan kerapatan massa udara. Panas tersebut akan membuat udara terdorong keluar pada celah sehingga kecepatan aliran pada ruangan meningkat.

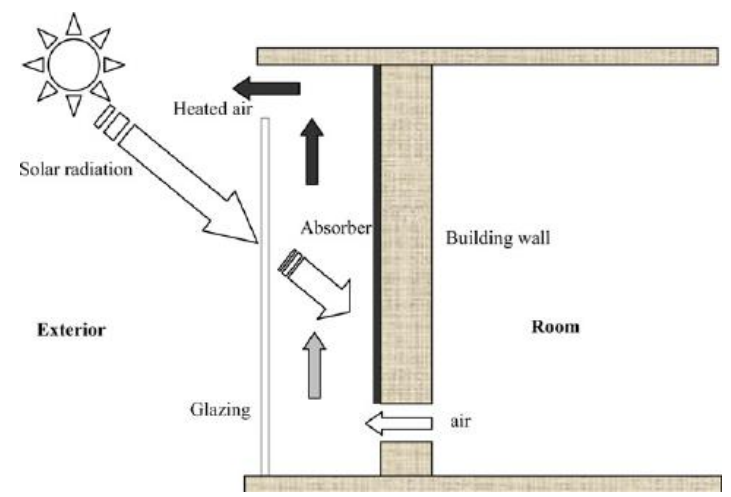

Gambar 3. Skema Dinding Trombe Pendingin Ruangan

Berbeda halnya pada daerah musim dingin, dinding trombe digunakan sebagai penghangat ruangan. Panas yang tersimpan pada dinding dikondisikan agar memanaskan ruangan di malam hari dan udara panas pada celah disalurkan ke dalam ruangan untuk dimanfaatkan sebagai penghangat ruangan pada siang hari.

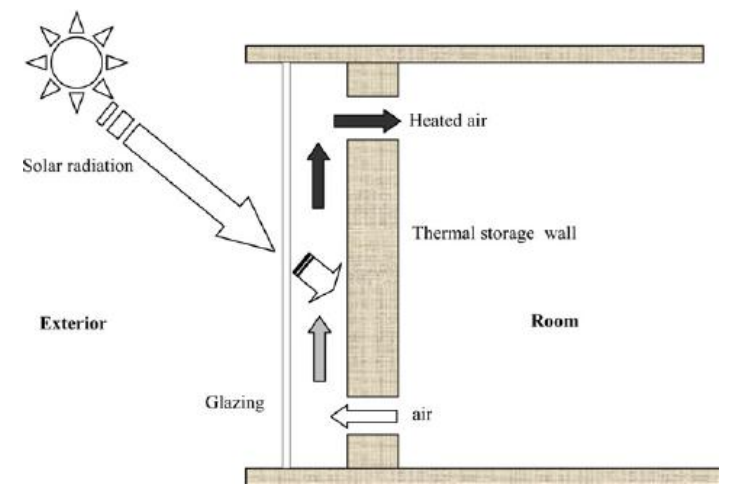

Gambar 4. Skema Dinding Trombe Penghangat Ruangan

\section{Konveksi Alami}

Konveksi alami adalah perpindahan panas pada suatu situasi dimana tidak ada gaya kecepatan fluida atau fluida di anggap diam. pada prosesnya gradien temperatur menyebabkan terjadinya perbedaan densitas di suatu permukaan benda. Gaya apung akan terjadi pada proses tersebut akibat penurunan densitas pada arah gaya gravitasi dan membentuk suatu sirkulasi natural dimana fluida yang terkena pengaruh sirkulasi ini akan otomatis bergerak melalui permukaan padat.

Parameter tak berdimensi yang menunjukan keserupaan seperti bilangan reynold pada fluida yang bergerak untuk menentukan jenis aliran fluida yang mengapung pada permukaan plat isothermal adalah bilangan Grashof. 
Persamaan Bilangan Rayleigh adalah hasil perkalian bilangan Grashof dengan Bilangan Prandtl.

Korelasi Empiris bilangan Nusselt pada plat vertikal untuk semua jenis aliran.

Korelasi Empiris angka Nusselt pada plat horizontal untuk jenis aliran laminer.

Korelasi Empiris angka Nusselt pada plat horizontal untuk jenis aliran turbulen

Korelasi Empiris bilangan Nusselt pada enklosur plat vertikal yang dimiringkan dengan aspek rasio $(\mathrm{H} / \mathrm{L} \lesssim 12)$.

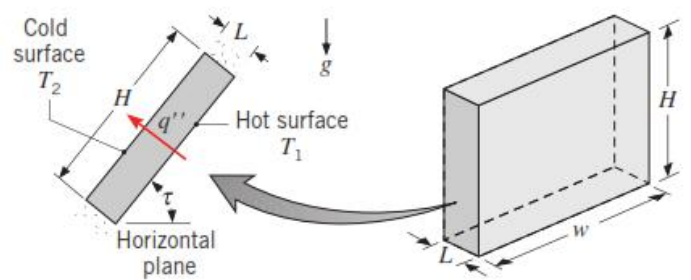

Gambar 5 Skema Rasio Aspek Pada Benda Rectangular

\section{TABLE 9.4 Critical angle for inclined rectangular cavities}

\begin{tabular}{lccccc}
\hline$(H / L)$ & 1 & 3 & 6 & 12 & $>12$ \\
$\tau^{*}$ & $25^{\circ}$ & $53^{\circ}$ & $60^{\circ}$ & $67^{\circ}$ & $70^{\circ}$ \\
\hline
\end{tabular}

Gambar 6. Sudut Kritis Pada Plat Rectangular yang dimiringkan

\section{METODELOGI PENELITIAN}

Pada penelitian ini menggunakan 2 buah ruangan ukuran $0,5 \mathrm{~m} \times 0,5 \mathrm{~m} \times 0,5 \mathrm{~m}$, satu ruangan memakai panel surya dan satunya lagi kondisi ruangan normal menggunakan kalsiboad pada channel outlet. Variabel bebas yang digunakan pada penelitian ini adalah variasi Channel Outlet (gap) yakni $3 \mathrm{~cm}, 4.5 \mathrm{~cm}$, dan $6 \mathrm{~cm}$. Sedangkan variabel terikat yang digunakan pada penelitian ini adalah temperatur, kelembaban, tegangan listrik, dan arus listrik. 


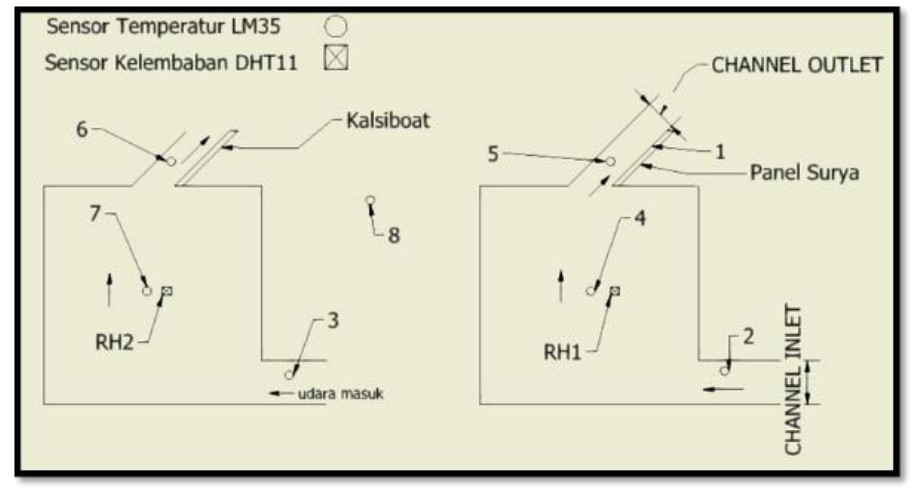

Gambar 7. Konsep Penelitian

Masing-masing variasi lebar celah dilaksanakan dengan interval waktu pengambilan data selama 10 menit. Sisi miring channel outlet $45^{\circ}$ dihadapkan ke arah utara.

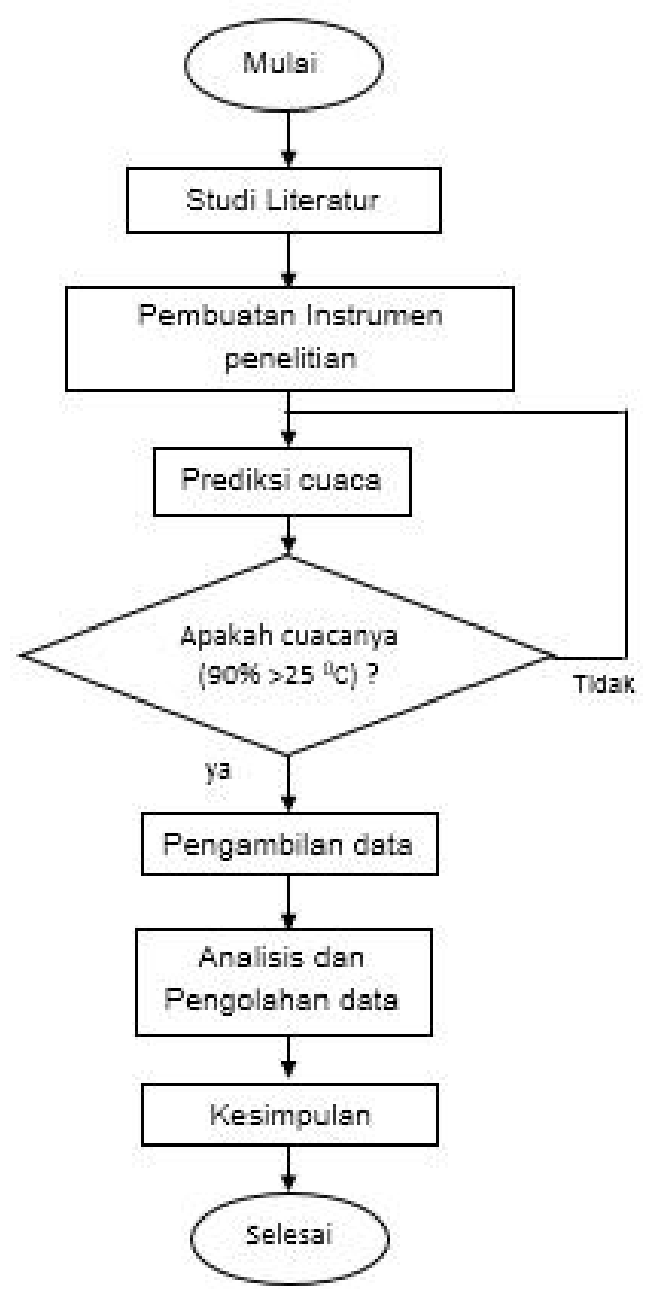

Gambar 8. Diagram penelitian

\section{HASIL DAN PEMBAHASAN}

Data dan Pembahasan Hasil Penelitian Temperatur Ruangan 
Grafik temperatur ruangan yang dihasilkan seiring bertambahnya lebar celah semakin meningkat. Peningkatan temperatur disebabkan oleh sinar matahari yang masuk pada kondisi ruangan dengan lebar celah semakin lebar maka penampang lubang keluar semakin besar dan semakin banyak pula sinar matahari yang masuk. Oleh karena itu temperatur akan meningkat karena sinar yang masuk bertambah banyak. Didapatkan pada kondisi ruangan lebar celah $3 \mathrm{~cm}$ dan 4,5 cm dengan menggunakan panel surya maupun kondisi normal dapat memanaskan ruangan dari temperatur lingkungannya. Sedangkan pada kondisi ruangan lebar celah $6 \mathrm{~cm}$ dengan menggunakan panel surya maupun kondisi normal dapat mendinginkan ruangan dari temperatur lingkungannya.

\section{Temperatur Ruangan Lebar Celah $3 \mathrm{~cm}$}

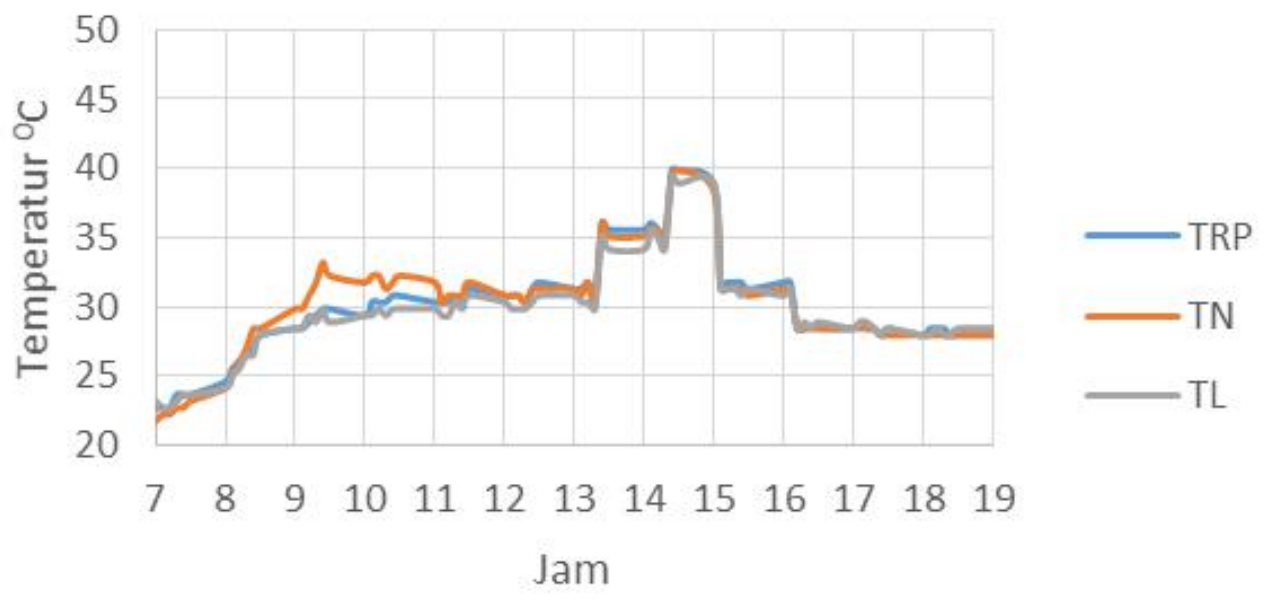

Gambar 9. Grafik Temperatur Ruangan Lebar Celah $3 \mathrm{~cm}$

Temperatur rata-rata kondisi ruangan pada lebar celah $3 \mathrm{~cm}$ yang menggunakan panel surya dan kondisi ruangan normal adalah $29.91193{ }^{\circ} \mathrm{C}$ dan $30.08225{ }^{\circ} \mathrm{C}$. Sedangkan temperatur rata-rata lingkungannya adalah $29.51323{ }^{\circ} \mathrm{C}$. Kondisi ruangan panel surya memanaskan ruangan dengan temperatur $0.3987{ }^{\circ} \mathrm{C}$ lebih tinggi terhadap temperatur lingkungan sedangkan ruangan normal memanaskan ruangan dengan temperatur $0.56902{ }^{\circ} \mathrm{C}$ lebih tinggi terhadap temperatur lingkungan. 


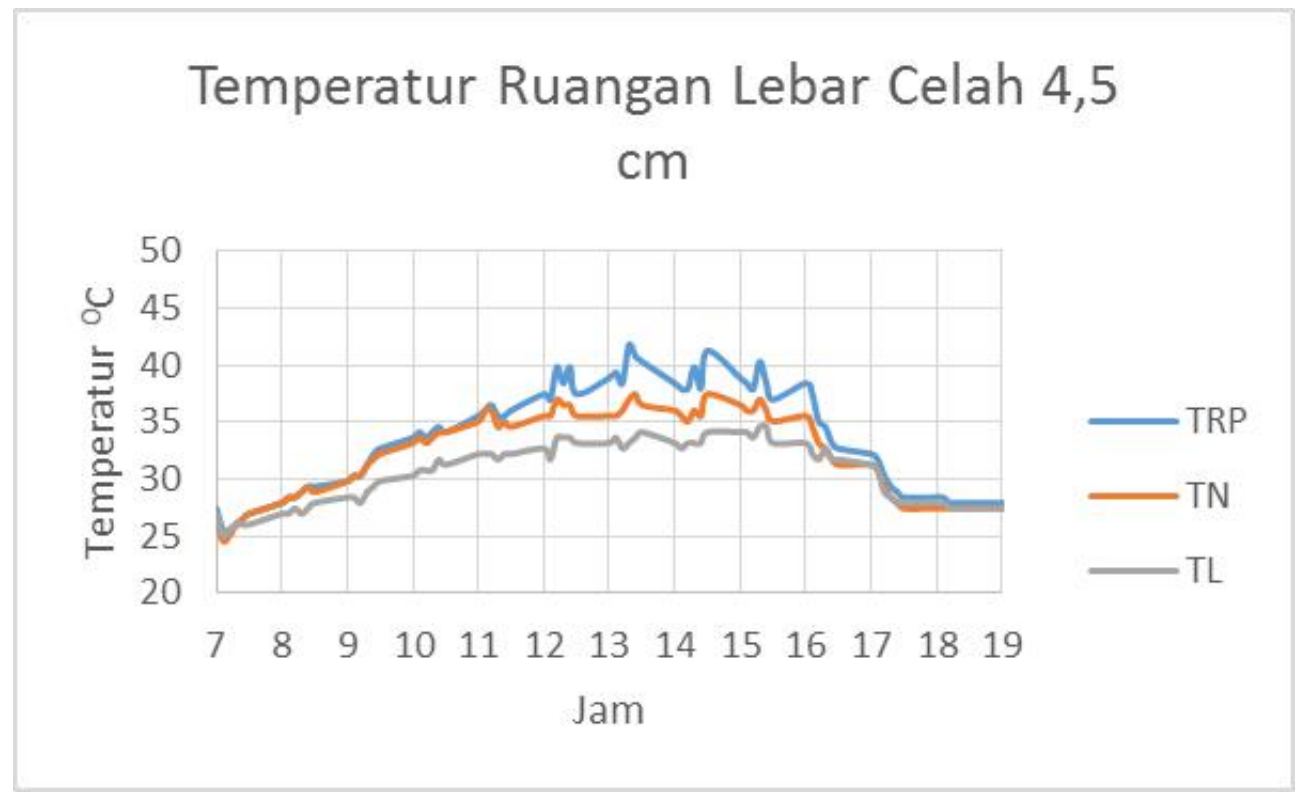

Gambar 10. Grafik Temperatur Ruangan Lebar Celah $4,5 \mathrm{~cm}$

Temperatur rata-rata kondisi ruangan pada lebar celah 4,5 $\mathrm{cm}$ yang menggunakan panel surya dan kondisi ruangan normal adalah $33.70706{ }^{\circ} \mathrm{C}$ dan $32.34814{ }^{\circ} \mathrm{C}$. Sedangkan temperatur rata-rata lingkungannya adalah $30.63668{ }^{\circ} \mathrm{C}$. Kondisi ruangan panel surya memanaskan ruangan dengan temperatur $3.07038{ }^{\circ} \mathrm{C}$ lebih tinggi terhadap temperatur lingkungan sedangkan ruangan normal memanaskan ruangan dengan temperatur $1.71146{ }^{\circ} \mathrm{C}$ lebih tinggi terhadap temperatur lingkungan.

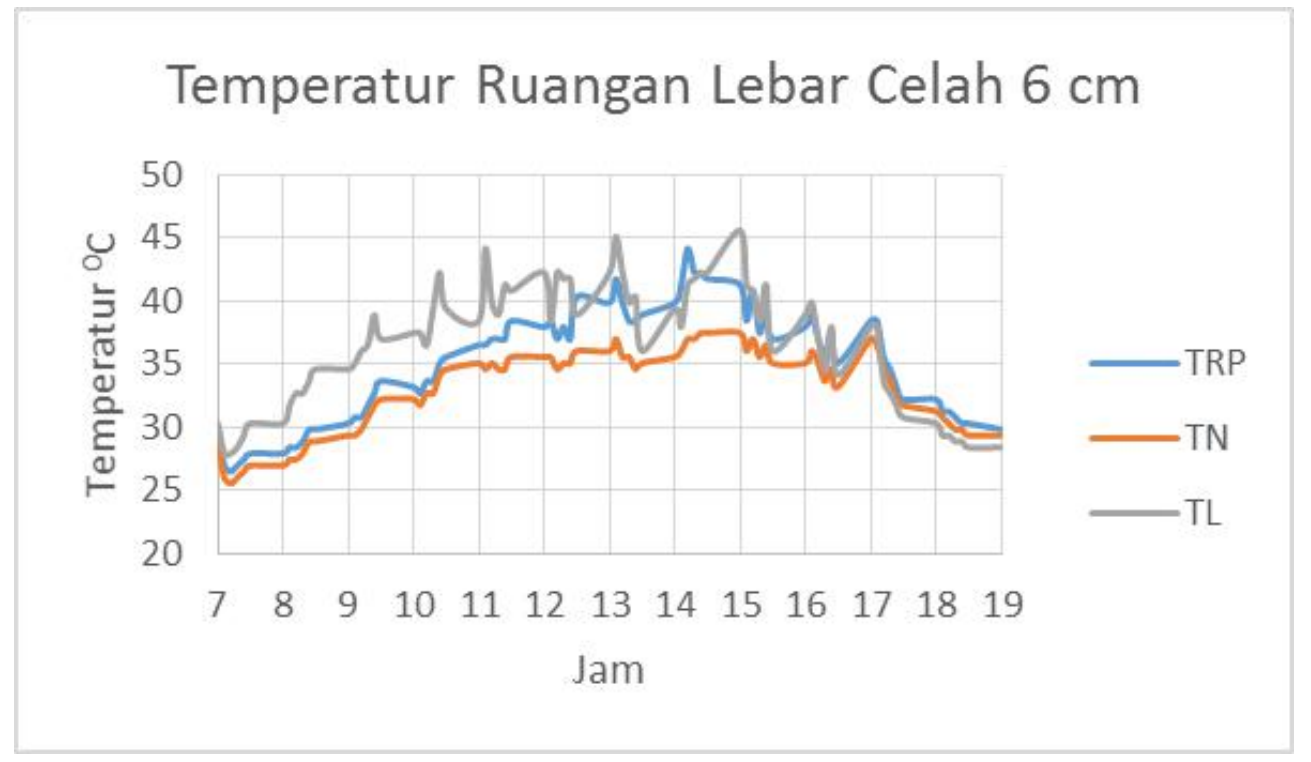

Gambar 11. Grafik Temperatur Ruangan Lebar Celah $6 \mathrm{~cm}$

Temperatur rata-rata kondisi ruangan pada lebar celah $6 \mathrm{~cm}$ yang menggunakan panel surya dan kondisi normal adalah $35.04658{ }^{\circ} \mathrm{C}$ dan $32.98084{ }^{\circ} \mathrm{C}$. Sedangkan temperatur rata-rata 
lingkungannya adalah $36.647{ }^{\circ} \mathrm{C}$. Kondisi ruangan panel surya mendinginkan ruangan dengan temperatur $1.60042{ }^{\circ} \mathrm{C}$ lebih rendah terhadap temperatur lingkungan sedangkan ruangan normal mendinginkan ruangan dengan temperatur $3.66616{ }^{\circ} \mathrm{C}$ lebih rendah terhadap temperatur lingkungan.

\section{- Data dan Pembahasan Hasil Penelitian Kenyamanan Udara.}
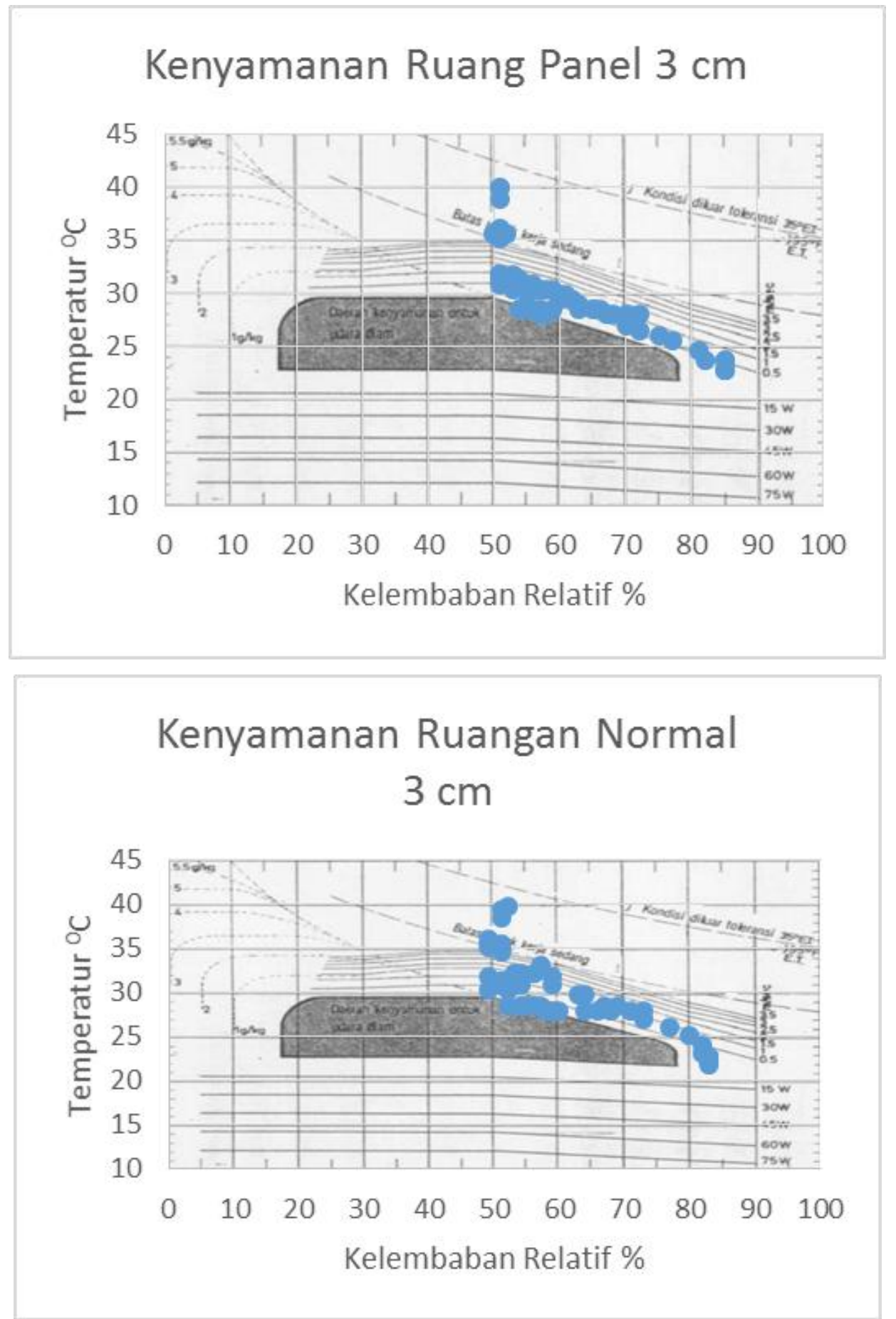

Gambar 12. Grafik Kenyamanan Udara Ruangan Lebar Celah 3 cm 
Kelambaban rata-rata yang dihasilkan dengan kondisi ruangan yang menggunakan panel surya dan kondisi normal pada lebar celah $3 \mathrm{~cm}$ adalah $59.5616 \%$ dan $58.671 \%$
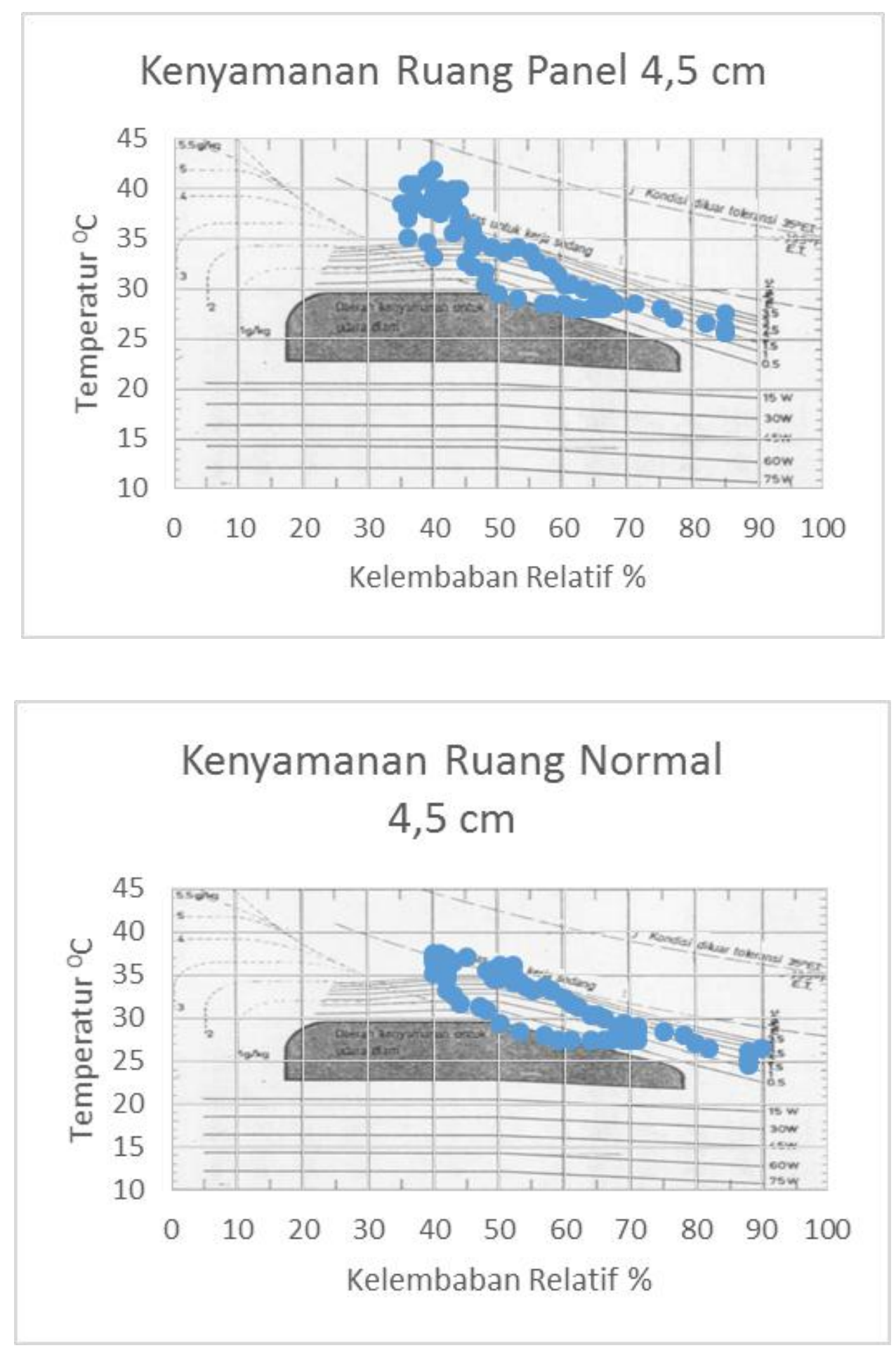

Gambar 13 Grafik Kenyamanan Udara Ruangan Lebar Celah 4,5 cm

Kelembaban rata-rata yang dihasilkan dengan kondisi ruangan yang menggunakan panel surya dan kondisi normal pada lebar celah $4,5 \mathrm{~cm}$ adalah $51.4932 \%$ dan $54.863 \%$. 

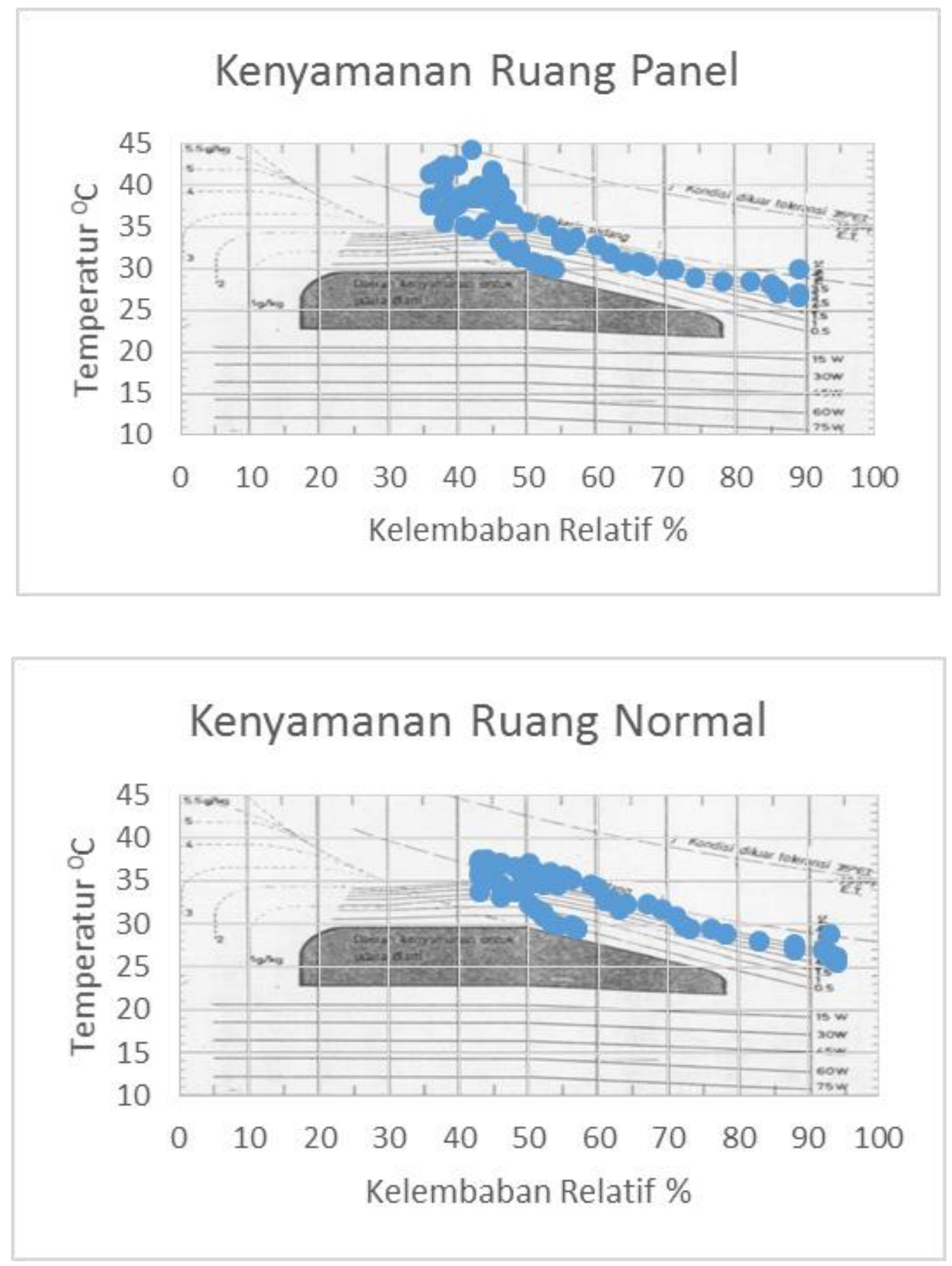

Gambar 14. Grafik Kenyamanan Udara Ruangan Lebar Celah 6 cm

Kelambaban rata-rata yang dihasilkan dengan kondisi ruangan yang menggunakan panel surya dan kondisi normal pada lebar celah $6 \mathrm{~cm}$ adalah $52.5068 \%$ dan $58.671 \%$.

Secara keselurahan pada semua lebar celah seiring meningkatnya temperatur pada ruangan maka akan menurunkan kelembaban yang ada pada ruangan tersebut. Ini disebabkan karena temperatur yang meningkat akan membuat udara memuai karena penurunan densitas pada kondisi tersebut sehingga tekanan udaranya akan berkurang. Tekanan yang berkurang akan 
meningkatkan volume pada udara tersebut sehingga kelembabannya rendah karena konsentrasi uap air pada kondisi tersebut menurun.

Kondisi ruangan dengan temperatur rata-rata yang tinggi akan membuat hasil plot kenyamanan udara secara keseluruhan akan renggang, sebaliknya jika temperatur rata-rata pada ruangan tersebut rendah akan membuat hasil plot kenyamanan udara secara keseluruhan akan terlihat merapat dan hampir seragam. Ini disebabkan pada temperatur rata-rata yang rendah tidak terjadi perubahan kelembaban secara drastis melainkan akan berubah secara bertahap.

\section{Data dan Pembahasan Hasil Penelitian Daya Listrik.}

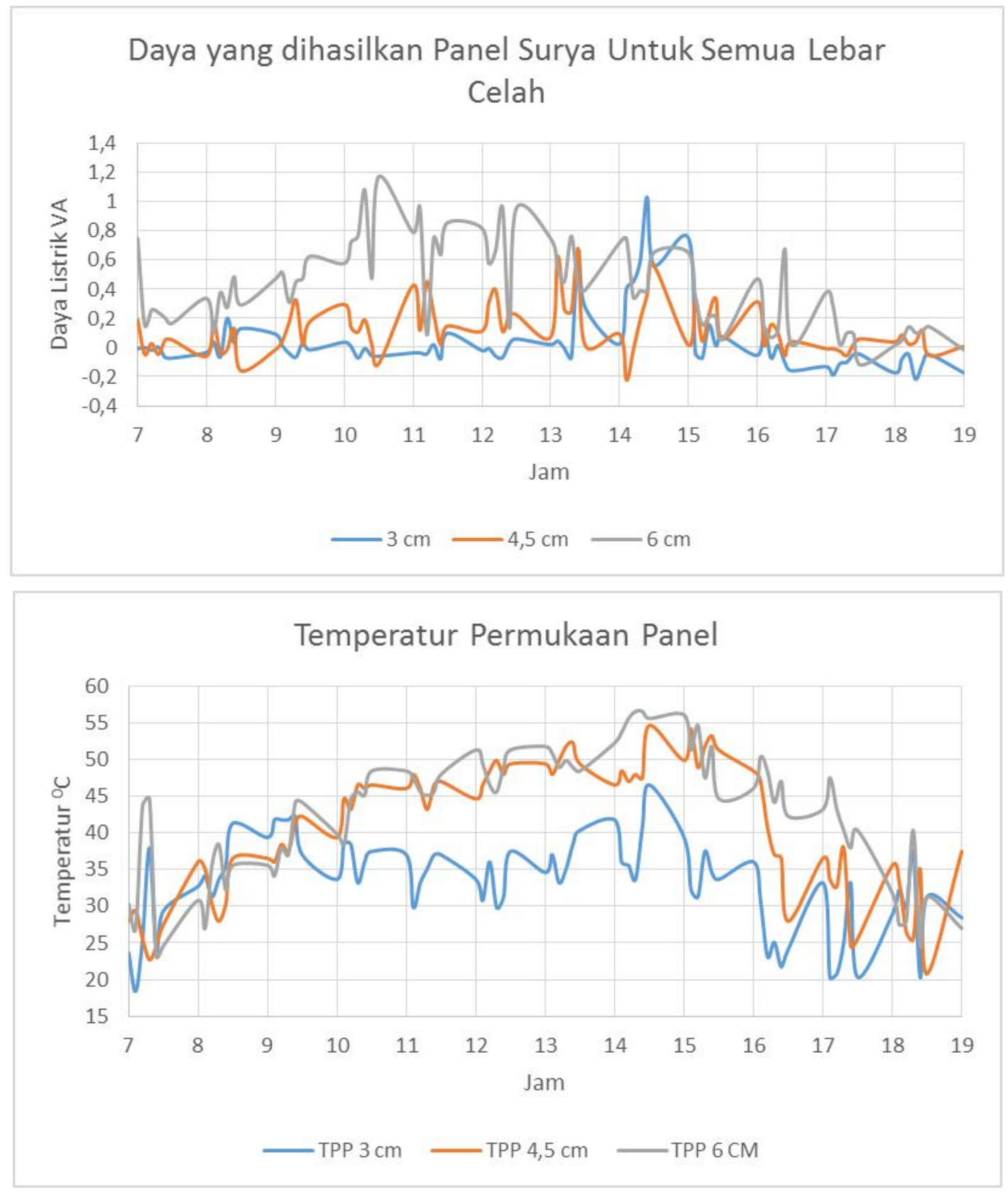

Gambar 15 Grafik Daya Listrik Panel Surya Dan Temperatur Permukaan Panel Surya 
Berdasarkan penelitian sebelumnya yang dilakukan oleh Koyunbaba, dkk (2012) didapatkan bahwa jika temperatur pada permukaan panel surya tinggi maka akan menurunkan efisiensi daya yang dihasilkan pada panel surya tersebut. Sebaliknya jika temperatur pada permukaan panel surya rendah maka akan meningkatkan efisiensi daya yang dihasilkan oleh panel surya. Pada gambar 4.3 lebar celah $6 \mathrm{~cm}$ menghasilkan daya rata-rata sebesar 0.417816 VA, lebar celah 4,5 cm menghasilkan daya rata-rata sebesar $0.125086 \mathrm{VA}$, dan lebar celah $3 \mathrm{~cm}$ menghasilkan daya rata-rata sebesar $0.04157 \mathrm{VA}$. terlihat bahwa daya rata-rata yang di hasilkan oleh lebar celah $6 \mathrm{~cm}$ lebih besar dibandingkan dengan lebar celah lainnya.

Kemudian didapatkan hasil temperatur rata-rata pada permukaan panel surya dengan lebar celah $6 \mathrm{~cm}$ adalah sebesar $42.9831{ }^{\circ} \mathrm{C}$, temperatur rata-rata pada permukaan panel surya dengan lebar celah $4,5 \mathrm{~cm}$ adalah sebesar $40.56615{ }^{\circ} \mathrm{C}$, dan temperatur rata-rata pada permukaan panel surya dengan lebar celah $3 \mathrm{~cm}$ adalah sebesar $33.16507{ }^{\circ} \mathrm{C}$. Terlihat bahwa temperatur rata-rata pada permukaan panel surya dengan lebar celah $6 \mathrm{~cm}$ lebih tinggi dibandingkan dengan temperatur rata-rata lebar celah lainnya. Kondisi ini berbanding terbalik dengan penelitian sebelumnya yang dilakukan oleh Koyunbaba, dkk (2012), ini disebabkan karena adanya perbedaan intensitas sinar matahari dan indeks kecerahan yang tidak konstan pada kondisi masing-masing hari tersebut. Ketidaksamaan intensitas cahaya dan indeks kecerahan ini akan mempengaruhi temperatur yg dihasilkan.

Kemudian pada channel outlet dengan lebar celah yang berbeda ketika matahari tepat tegak lurus diatas ruangan maka ada perbedaan paparan sinar matahari yang diterima pada permukaan panel surya. Semakin lebar celah pada channel outlet ruangan semakin banyak permukaan panel surya yang terpapar langsung oleh sinar matahari tanpa melewati kaca akibat jarak antara kaca dengan panel surya semakin jauh. Sehingga daya yang dihasilkan pada lebar celah $6 \mathrm{~cm}$ lebih besar karena pada permukaan panel suryanya lebih banyak terpapar langsung oleh sinar matahari dan temperatur rata-rata permukaannya paling tinggi. Sedangkan daya yang dihasilkan pada lebar celah $3 \mathrm{~cm}$ paling kecil karena permukaan panel surya terhalang banyak oleh kaca dan temperatur rata-rata permukaannya paling kecil 


\section{Data dan Pembahasan Hasil Penelitian Bilangan Nusselt}

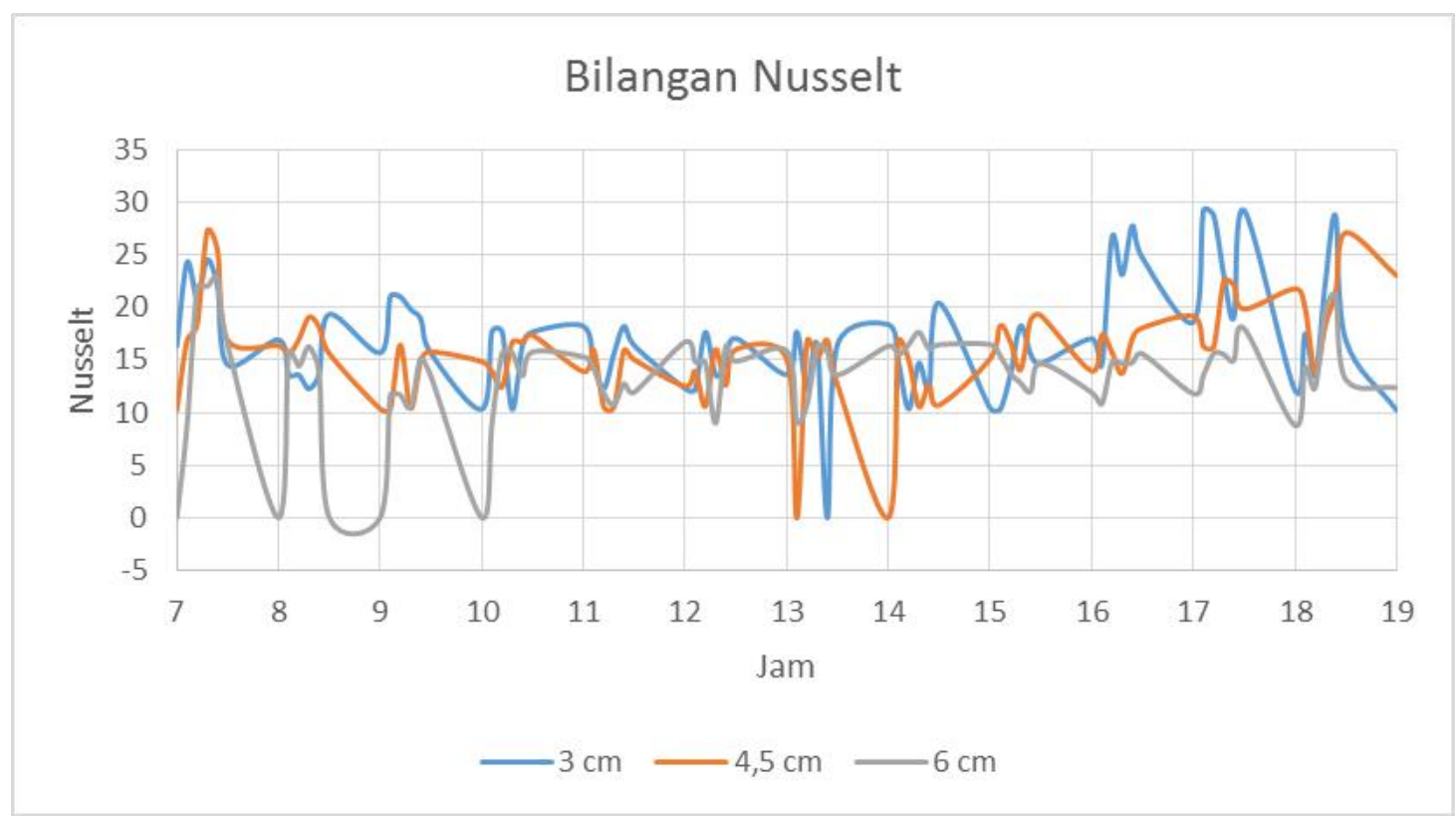

Gambar 16 Grafik Bilangan Nusselt Untuk Semua Lebar Celah

Untuk mengetahui aliran panas pada permukaan panel surya hingga ke udara yang ada diantara kaca dengan panel surya maka dari itu diperlukan suatu parameter bilangan nusselt. Bilangan nusselt akan menentukan seberapa besar aliran panas pada suatu permukaan yang mana tergantung dari jenis aliran fluida yang melewati permukaan panel tersebut. Semakin turbulen jenis aliran fluida maka semakin aktifnya aliran panas pada permukaan tersebut. Pada grafik bilangan nusselt terlihat bahwa ketiga lebar celah hampir seragam namun ada lonjakan kebawah yang disebabkan selisih temperatur antara permukaan panel dengan udara yang kontak dengan permukaannya adalah sama besar atau tidak ada selisih diantaranya. Bilangan nusselt rata-rata yang terjadi pada lebar celah $3 \mathrm{~cm}$ adalah sebesar 17.13149313, bilangan Nusselt ratarata yang terjadi pada lebar celah $4.5 \mathrm{~cm}$ adalah sebesar 15.78699459 , dan bilangan Nusselt rata-rata pada lebar celah $6 \mathrm{~cm}$ adalah sebesar 13.51249177 .

kondisi ruangan lebar celah $3 \mathrm{~cm}$ memiliki bilangan nusselt paling tinggi dibandingkan dengan lebar celah lainnya. Artinya aliran panas yang terjadi pada lebar celah $3 \mathrm{~cm}$ lebih aktif dibandingkan dengan lebar lainnnya. Ini disebabkan karena volume udara yang ada pada lebar celah $3 \mathrm{~cm}$ lebih sedikit dibandingkan lebar celah lainnya sehingga memudahkan panas untuk mengalir secara konveksi dan konduksi pada kondisi tersebut. 


\section{Pembahasan Umum}

Temperatur rata-rata ruangan panel surya dengan lebar celah $3 \mathrm{~cm}$ adalah temperatur ruangan yang paling dingin dibandingkan dengan temperatur rata-rata ruangan panel surya dengan lebar celah lainnya sehingga kenyamanan udara yang dihasilkan pada ruangan inilah yang paling mendekati daerah standar kenyamanan udara dibandingkan pada ruangan dengan lebar celah lainnya. Namun daya yang dihasilkan pada lebar celah ruangan ini paling kecil.

Berkaitan dengan pembahasan sebelumnya bilangan nusselt rata-rata pada lebar celah $3 \mathrm{~cm}$ ini menghasilkan nilai yang paling besar. Hal ini disebabkan temperatur film rata-rata yang didapatkan lebih kecil dari yang lain. Terlebih lagi gradien temperatur rata-rata yang dihasilkan lebih tinggi untuk porsi temperatur film rata-rata yang didapatkan pada lebar celah ini. Hal ini lah yang akan mempengaruhi nilai-nilai properti termodinamika untuk kondisi udara tersebut. Yang mana jika temperatur film yang dihasilkan semakin rendah maka akan meningkatkan koefisien ekspansi volume udara dan bilangan prandtl, tetapi akan menurunkan viskositas kinematik pada udara tersebut ditambah dengan gradien temperatur yang tinggi. Kondisi ini lah yang membuat aliran panas semakin aktif pada permukaan panel surya tersebut sehingga udara panas terdorong habis keluar. Terlebih lagi volume udara yang ada pada lebar celah $3 \mathrm{~cm}$ paling kecil dibandingkan dengan lebar celah lainnya sehingga memudahkan aliran panas mengalir secara konveksi dan konduksi pada kondisi tersebut. Ini terbukti pada gambar grafik temperatur ruangan pada lebar celah $3 \mathrm{~cm}$ sebelumnya terlihat ruangan yang menggunakan panel surya lebih dingin dibandingkan dengan temperatur normalnya. Yang mana untuk lebar celah lainnya temperatur ruangan dengan panel surya lah yang lebih panas dibandingkan dengan temperatur ruangan normalnya.

\section{KESIMPULAN}

Berdasarkan hasil penelitian kesimpulan yang dapat diambil adalah sebagai berikut :

1. Pengaruh lebar celah channel outlet atau ventilasi terhadap kondisi ruangan dengan menggunakan panel surya sebagai penyimpan panas dan tanpa penyimpan panas adalah jika semakin lebar celah channel outlet atau ventilasi maka akan meningkatkan temperatur pada ruangan, menurunkan kelembaban ruangan, dan menurunkan kenyamanan pada ruangan tersebut.

2. Semakin lebar celah ventilasi pada suatu kondisi ruangan maka daya listrik yang dihasilkan oleh panel surya akan meningkat. 


\section{DAFTAR PUSTAKA}

1. Bergman, Theodore L., Lavine, Adrienne S., Incropera, Frank P. Dan Dewitt, David P. 2011. Fundamentals of Heat and Mass Transfer. 7nd edition. John Willey \& Sons.

2. Duffie, John A. Dan Beckman, William A. 2013. Solar Engineering pf Thermal Process. 4nd edition. John Wiley \& Sons.

3. Febrita, Yuswinda. 2011. Ventilasi Solar Cimney Sebagai Alternatif Desain Passive Cooling di Iklim Tropis Lembab (Jurnal).

4. Koyunbaba, Basak Kundacki. dan Yilmaz, Zerrin. 2012. The Comparison of Trombe Wall Systems with Single Glass, Double glass and PV panels.

5. Lippsmeier, Georg (1994), Tropenbou Building in the Tropics, Bangunan Tropis (terj.), Jakarta: Erlangga.

6. Luque, Antonio. Dan Hegedus, Steven. 2011. Handbook of Photovoltaic Science and Engineering. 2nd Edition. John Wiley \& Sons.

7. Mertens, Konrad. 2014. Photovoltaics Fundamentals, Technology and Practice. Munich/FRG. John Willey \& Sons.

8. Stoecker, W.F. dan Jones, J. W. 1982. Refrigeration and air conditioning. Edisi kedua. McGraw-Hill. NewYork.

9. Sun, Wei., Ji, Jie., Luo, Chenglong., dan He, We. 2011. Performance of PV-Trombe wall in winter correlated with south facade Design (Jurnal).

10. Welty, James R., Wicks, Charles E., Wilson, Robert E., Dan Rorrer, Gregory. 2000. Dasar-dasar Fenomena Transport. Corvallis Oregon. Penerbit : Erlangga 